\title{
SECTION 16(d) OF THE SECURITIES \\ EXCHANGE ACT: LEGISLATIVE COMPROMISE OR LOOPHOLE?
}

\author{
WILLiam H. Painter $\dagger$
}

The date was Thursday, November 2, 1933. Ferdinand Pecora, Counsel to the Subcommittee of the Senate Committee on Banking and Currency appointed to investigate stock exchange practices in the aftermath of the 1929 disaster, was questioning Albert H. Wiggin, retired, formerly President of the Chase National Bank. The questioning that day involved the affairs of the Brooklyn-Manhattan Transit Corporation, of which Wiggin was fortunate to have been Chairman of the Finance Committee. In June of the previous year the decision as to whether Brooklyn-Manhattan Transit would have to pass its dividend had been largely dependent upon the attitude of Wiggin's Chase National towards certain planned financing. Mr. Wiggin was embarrassed as he testified:

Mr. Pecora. And would not the passing of the dividend be a matter on which you would exercise, as chairman of the finance committee, a considerable weight?

Mr. WIGGIN. I think so.

Mr. PeCORA. And when did you first reach the conclusion that, from your judgment at least, the board should pass the dividend?

$M_{R}$. WIGGIN. I think at the time I sold the stock.

Mr. Pecora. And it was about the same time that Mr. Dahl, the chairman of the board, sold large holdings of the stock?

Mr. WIGGIN. Yes, sir.

Mr. Pecora. Now, after the dividend was passed there was a marked depreciation of the market value of the stock, was there not?

Mr. WIGGIN. Yes, sir.

Mr. Pecora. Is it fair to assume that the reasons that prompted you and Mr. Dahl to sell these holdings of your

$\dagger$ Professor of Law, Villanova University. A.B. 1950, Princeton University; LL.B. 1954, Harvard University. Member, New York Bar. 
B.M.T. common stock is the knowledge that you had of the financial condition of the company, which knowledge you acquired as the chairman of the finance committee and the chairman of the Board, respectively?

$M_{R}$. WIGGIN. Yes, I had no inside information, except the knowledge that influenced my judgment was the maturity of the notes, and everybody knew about it. ${ }^{1}$

In five days of trading, Brooklyn-Manhattan Transit Corporation stock had fallen from a high of 25 to a low of $11 \frac{1}{\mathrm{~s}}$, but Mr. Wiggin and his associates had made a handsome profit.

To prevent such abuses of fiduciary duties by corporation directors and officers, ${ }^{2}$ Congress enacted section 16 of the Securities Exchange Act of $1934,{ }^{3}$ known in its early years as the "anti-Wiggin" propoșal.

\section{Section $16(\mathrm{~b})$}

Section 16(b), sometimes referred to as the "short-swing trading" provision, creates a corporate cause of action to recover any "profit realized" on the purchase and sale, or sale and purchase, of an equity security by officers, directors, or beneficial owners of more than ten percent of a class of equity security. The section applies, however, only to stock registered on a national exchange, or registered under the Securities Exchange Act where the number of equity security holders in any class is 750 or more, and the issuer's total assets exceed $\$ 1,000,000 .{ }^{4}$ This recovery is a potent deterrent to so-called "insider" trading of the "short-swing" variety, although its application only to purchases and sales within a six-month period leaves uncovered at least some advantageous uses of inside information.

The provision does not prohibit the use of inside information; it only makes its use unprofitable in "short-swing" transactions. Initially, Congress had considered making the use itself unlawful while permitting the corporation to recover profits from persons to whom such information was disclosed. It was felt, however, that such a provision would be unenforceable because of the problem of proof. Hence a so-called "objective" test was adopted, making it

1 Hearings on S. 84 and S. 56 Before the Senate Committee on Banking and Currency, 73d Cong., 1st Sess., pt. 4, at 3024-28 passim (1933).

2 S. REp. No. 1455, 73d Cong., $2 d$ Sess. 55 (1934).

348 Stat. 881 (1934), 15 U.S.C. $\$ 78$ (1958), as amended 15 U.S.C. \$ 78 (Supp. IV, 1963).

4 Prior to the recent securities acts amendments, only issuers having an equity security registered on a national stock exchange were covered. Within 120 days after the last day of an issuer's fiscal year ended two years from July 1, 1964, the effective date of the new legislation, the requisite number of equity security holders will be reduced from 750 to 500 , thus broadening the coverage of the overthe-counter market. Securities Exchange Act of 1934, §12(g), 48 Stat. 892, as amended, 78 Stat. 566 (1964). 
immaterial whether or not the "insider" possessed, much less made use of, confidential information. ${ }^{5}$ This "crude rule of thumb," ${ }^{6}$ with all its shortcomings, has on the whole functioned well. If anything the courts have been eager to construe the statute in a manner which seems at times almost "penal" in order to carry out "the statutory purpose." 7

Section 16(b) has been conspicuously ineffective in coping with the "insider-partner" who sits as a representative of his firm on a corporate board of directors. This practice, prevalent throughout the securities industry, of partnership representation on corporate boards has at times seemed to threaten an evisceration of the statutory purpose. Consider the case of Cady, Roberts \& Co. ${ }^{8}$

J. Cheever Cowdin, a registered representative of Cady, Roberts \& Company was a member of the board of directors of Curtiss-Wright Corporation. On the morning of November 25, 1959, the board met to consider, among other things, the declaration of the regular quarterly dividend. Prior to that date there had been considerable publicity concerning a new type of internal combustion engine under development by the company. As a result, the stock had risen approximately fourteen percent in a three-day period. Through its partner, Robert M. Gintel, Cady, Roberts \& Company had been actively purchasing the stock for various accounts throughout most of the period of the price rise. At the directors' meeting, the board declared a fourthquarter dividend at a rate reduced from that of the dividends for the previous three quarters which, although paid, had been unearned. The news of the board's action was authorized for transmission by telegram to the New York Stock Exchange at approximately 11:00 a.m., but the telegram, although transmitted to Western Union at $11: 12$ a.m., was not actually delivered to the Exchange until $12: 29$ p.m. due to typing problems. Meanwhile, the announcement had appeared on the Dow Jones ticker at 11:48 a.m. Before the information had appeared on the tape, however, and no later than 11:15 a.m., Cowdin, an authorized representative of Cady-Roberts, left the directors' meeting during a recess and called his office, informing Gintel that the dividend had been cut. Gintel thereupon commenced selling the Curtiss-Wright stock for various accounts, some of the sales being

5 See Smolowe v. Delendo Corp., 136 F.2d 231, 235-36 (2d Cir.), cert. denied, 320 U.S. 751 (1943); Hearings on $S .84, S .56$, and $S .97$ Before the Senate Committee on Banking and Currency, 73d Cong., 2d Sess., pt. 15, at 6557 (1934).

6 Ibid.

7 See, e.g., Gratz v. Claughton, 187 F.2d 46, 52 (2d Cir.), cert. denied, 341 U.S. 920 (1951). See generally Painter, The Evolving Role of Section 16(b), 62 Mich. L. REv. 649 (1964).

8 SEC Securities Exchange Act Release No. 6668, Nov. 8, 1961. 
short-sales. When the news of the reduced dividend became public at $11: 48$ a.m., trading in Curtiss-Wright stock was suspended due to a flood of sell orders and was not resumed until 1:59 p.m. By the close of the day, the price of the stock had fallen fifteen percent since the opening.

This was not a section $16(\mathrm{~b})$ case, but it could have been. Rather, it was a disciplinary proceeding brought by the Securities and Exchange Commission for violation of the antifraud provisions of section 10(b) of the Securities Exchange Act of $1934^{\circ}$ and section 17 (a) of the Securities Act of $1933 .^{10}$ As a result the Commission suspended Gintel for twenty days from trading on the New York Stock Exchange, which had already imposed a fine of $\$ 3,000$ upon him. Although the Commission also found that Cady-Roberts had violated the securities acts through Gintel, no action was taken against it nor against Cowdin, since the latter might have assumed at the time he telephoned that the news of the reduced dividend had already been made public. Gintel, on the other hand, knew that the news had not yet appeared on the Dow Jones ticker.

To impose section 16(b) liability upon Cowdin or Cady, Roberts \& Company, it would not have been necessary to show that either took advantage of "inside" information, nor would it even have been necessary to prove that there was inside information. Purchase followed by a sale within six months at a profit would suffice. Oddly enough, Gintel would not have been liable, since section $16(\mathrm{~b})$ does not make unlawful the use of inside information by those to whom it has been disclosed by an "insider." 11 Cady-Roberts's possible liability is more difficult to handle. If the firm were the beneficial owner of more than ten percent of a class of registered equity securities of Curtiss-Wright Corporation, it would automatically fall within the scope of section $16 .^{12}$ If not, the problem becomes more complicated.

In order to simplify the matter slightly, let us assume that Cowdin was not merely a registered representative of Cady-Roberts but also a partner. ${ }^{13}$ The issue then becomes whether the firm

048 Stat. 891 (1934), 15 U.S.C. $\S 78 \mathrm{j}$ (1958).

1048 Stat. 84 (1933), 15 U.S.C. \$77q (1958).

11 See note 5 sipra.

12 This would be so even if the transaction (i.e., purchase) which gave rise to the liability increased the firm's interest from less than $10 \%$ to more than $10 \%$. Stella v. Graham-Paige Motors Corp., 104 F. Supp. 957 (S.D.N.Y. 1952), rev'd on other grounds, $232 \mathrm{~F} .2 \mathrm{~d} 299$ (2d Cir. 1956). The reasoning of this case possibly should apply only to sales followed by purchases rather than purchases followed by sales. See Painter, supra note 7, at 659 .

$13 \mathrm{He}$ would of course be liable personally under $\S 16(\mathrm{~b})$ in either event, since he was a director of Curtiss-Wright Corporation. 
is a "director" of Curtiss-Wright Corporation for the purpose of imposing section 16(b) liability upon it. Although the Uniform Partnership Act, codifying generally accepted principles of partnership law, considers the act of a partner to be that of the partnership for the purpose of binding it in tort or contract, ${ }^{14}$ the partnership and the partner are certainly not identical. Thus even though a partner's knowledge may be imputed to the partnership, ${ }^{15}$ liability cannot be imposed upon the partnership unless it is to be considered a "director" for purposes of section 16(b). As we have seen, parties to whom insider information is disclosed are not liable if they choose to act upon it. ${ }^{18}$

\section{BLAU v. LEHMAN}

This analysis is strikingly confirmed by the controversial case of Blau v. Lehman. ${ }^{17}$ There a director of Tide Water Associated Oil Company, Joseph H. Thomas, was also a partner of Lehman Brothers, New York investment bankers. Lehman Brothers purchased 50,000 shares of Tide Water common stock apparently without the knowledge of Thomas. When the transaction was called to his attention, Thomas instructed his firm to exclude him from any risk of the purchase and from any profit or loss arising from the sale of these securities. The instructions were carried out when Lehman Brothers subsequently converted the stock into 50,000 shares of preferred and sold them at a profit. The court held that the conversion of the common stock into preferred was a purchase within the meaning of that term in section $16(\mathrm{~b}),{ }^{18}$ and that the waiver of Thomas was a "realization" of profit from a short-swing transaction, thus rendering him liable for his proportionate share in the firm's profit. But it found that Lehman Brothers itself was not liable. Proceeding on the authority of an earlier decision, Rattner v. Lehman Bros., ${ }^{19}$ which similarly had found no liability, the court adopted what had been dictum in a concurring opinion of Judge Learned Hand, who had said that he wished "to say nothing as to whether, if a firm deputed a partner to represent its interests as a director on the board, the other partners would not be liable. . . ." 20 The court in Blau made "deputization"

14 UNIFORM PARTNERSHIP ACT $\$ 9$.

15 UNIFORM PARTNERSHIP ACT $\$ 12$.

16 See text accompanying notes 5, 11 supra.

17 Blau v. Lehman, 173 F. Supp. 590 (S.D.N.Y. 1959), aff'd, 286 F.2d 786 (2d Cir. 1960), aff'd, 368 U.S. 403 (1962). at $659-62$.

18 The litigation in this troublesome area is discussed in Painter, supra note 7,

18193 F.2d 564 (2d Cir. 1952).

$20 \mathrm{Id}$. at 567. 
the test of liability and found it to be lacking. The precise nature of this deputization, however, is not clear. Although the attention of Tide Water's president was called to Thomas by the latter's partner and predecessor on the board of directors, Hertz, the district court found that "the invitation to join the Tide Water Board was upon the initiative of Tide Water." ${ }^{21}$ Hence there was no evidence of deputization.

The Blau decision was not without its critics. A Supreme Court dissent augments Judge Clark's exceptionally vigorous dissent below. Mr. Justice Douglas termed the decision a "mutilation of the Act," 22 and claimed that "what the Court does today is substantially to eliminate 'the great Wall Street trading firms' from the operation of $\S 16(\mathrm{~b}) . "{ }^{23}$ Judge Clark had taken essentially the same position and pointed out that the legislative history on which the majority relied, specifically the abandonment of earlier drafts of the bill which would have permitted recovery of profits from persons to whom disclosure of inside information had been made, really argued for the opposite result. The difficulties of proof which were anticipated from the original proposal were thought so troublesome, Judge Clark reasoned, that the draft was abandoned in favor of a so-called "objective" test which would allow "automatic application of the statute without the necessity of proving the parties' intent." 24 Thus the position reached by the majority conflicted, in his view, with the whole thrust of the statute, which had sought to avoid a "subjective standard of proof, requiring a showing of an actual unfair use of inside information." 25

If the "deputization" doctrine is allowed to stand, a special exception to the coverage of the act is clearly being created not merely for "the great Wall Street trading firms," ${ }^{26}$ but for any well organized business concern which is understanding enough to avert its gaze while officers and other highly placed employees become directors in companies in which it is interested. If this form of mutual financial back-scratching is permitted, the purpose of the act is totally negated.

The Blau decision itself allows "all but one partner to share in the feast which the one places on the partnership table. They in turn can offer feasts to him in the 99 other companies of which they are

21 Blau v. Lehman, 173 F. Supp. 590, 592 (S.D.N.Y. 1959).

22368 U.S. at 415.

23 Id. at 414.

24286 F.2d at 794.

25 Ibid. The court quoted from Smolowe v. Delendo Corp., 136 F.2d 23i, 236 (2d Cir. 1943).

26368 U.S. at 414. 
the directors." $2 \pi$ Even under Blau, however, it might have been possible to surmount the technical problems entailed in viewing the partnership as a "director" under section $16^{28}$ by holding the insiderpartner liable for the entire amount of the profits realized on the transaction, instead of merely for his distributive share. This the majority, following the Rattner holding, expressly refused to do.

In Rattner the court emphasized the presence of the terms "any profit realized by him" in the statute and reasoned that the amount realized by the insider could never exceed his proportionate share in the firm profits, unless, perchance, he had "caused the firm to make them." ${ }^{29}$ Such reasoning, although justified by the literal terms of the statute, makes the extent of liability depend upon the partnership agreement. With sufficient ingenuity it is thus possible to defeat the statutory purpose by appropriate contractual arrangements between partners before the transaction takes place, as was the situation in the Blau case, rather than after.

However, even if the statute were so interpreted as to reach all profits connected with an insider-partner, we are still left with the possibility that the insider-director might not be a partner. He might be merely an employee of the firm, as was the case in Cady, Roberts \& $\mathrm{Co}^{30}$ and hence have no right to share in the profits of the transaction. Thus we reach the broader implications of the Blau and Rattner holdings, which presumably extend to incorporated brokerage houses, banks, insurance companies, and other financial institutions.

\section{Section 16(d)}

Even before the Supreme Court affirmed Blau, the question of these broader implications had been placed on the agenda of the Special Study of Securities Markets, established by congressional authorization. ${ }^{31}$ The results of the Study indicated that, although representation of broker-dealer firms on the boards of corporations whose stock was also traded was not as widespread as might have been supposed, ${ }^{32}$ the possibilities for abuse of the Blau doctrine by large investment firms were sufficiently grave to justify its legislative "reversal." 33 However, in order to ameliorate the proposal's effect

27 Id. at 420.

28 See text accompanying note 15 supra.

29 Rattner v. Lehman, 193 F.2d 564, 565 (2d Cir. 1952).

30 See text accompanying note 8 sipra.

31 The study was undertaken by a Special Study Group of the SEC pursuant to 75 Stat. 465 (1961), 15 U.S.C. $\$ 78$ s (d) (Supp. V, 1964).

32 SEC, Report of Special Study Group of Securities Markets, H.R. Doc. No.

95, 88th Cong., 1st Sess., pt. 3, at 44 (1963) [hereinafter cited as Special Study].

33 Id. at 64 . 
on accepted industry practices, the Special Study Group proposed limited ad hoc exemptions for so-called "market-makers," whose function it is to provide a central source of offers to buy and sell a company's securities in order to insure marketability and liquidity in investments, particularly in small concerns which have just completed their first public offering. In view of the potentiality of harm inherent in board representation of broker-dealer firms, such a limitation was thought more desirable than a general exemption for market-makers. ${ }^{34}$

As a result of the efforts of the Special Study Group, the Commission proposed comprehensive legislation to amend both the Securities Act of 1933 and the Securities Exchange Act of 1934.55 Only two of these proposals are relevant here. The first and most comprehensive change provided for broadening the reporting, proxy, and insider trading provisions to include securities dealt in over the counter through a new classification of these securities as "OTClisted." This group would include securities of corporations with a class of 750 or more equity security holders and total assets in excess of one million dollars. After a two-year period the coverage would be extended to include issuers having a class of only 500 or more equity security holders. ${ }^{36}$ A more surprising change, however, was the Commission's proposal of a new subsection to be known as section 16(d). As eventually adopted by Congress, it provides:

(d) The provisions of subsection (b) of this section shall not apply to any purchase and sale, or sale and purchase, and the provisions of subsection (c) of this section shall not apply to any sale, of an equity security not then or theretofore held by him in an investment account, by a dealer in the ordinary course of his business and incident to the establishment or maintenance by him of a primary or secondary market (otherwise than on a national securities exchange or an exchange exempted from registration under section 5 of this title) for such security. The Commission may, by such rules and regulations as it deems necessary or appropriate in the public interest, define and prescribe terms and conditions with respect to securities held in an investment account and transactions made in the ordinary course of business and incident to the establishment or maintenance of a primary or secondary market. ${ }^{37}$

Thus despite the recommendations of the Special Study Group, the Commission chose to adopt the alternative "solution" to the Blau 
problem, by providing for a general "market-making" exemption to the newly-extended coverage of section (b) for brokers or dealers rather than in effect "reversing" the Blau case and permitting the Commission to grant exemptions ad hoc for market-makers. The Commission's reasons for not following the Special Study Group's recommendations are not particularly convincing. As expressed at the Senate hearings, they amounted to a wish to "obviate the necessity of considering applications for exemption on an ad hoc basis" in view of the Commission's already existing powers "to curb by alternative means the misuse of inside information" by brokers and dealers, such as regular periodic inspections, reporting requirements under section $16(\mathrm{a})$, and the antifraud provisions of the securities acts. ${ }^{38}$

The Commission, in fact, has not been averse to $a d$ hoc exemptions in exercising various other regulatory powers. ${ }^{39}$ Thus, if the Commission favored a general prohibition of insider trading by brokerdealer firms, the "necessity of considering ad hoc exemptions" would likely not pose much of an obstacle. It is possible, of course, that the Commission did not consider the situation created or, perhaps, tolerated by the Blau and Rattner decisions sufficiently serious to warrant drastic legislative reversal. However, the Commission, curiously, had sought leave in the Blau case to file a brief amicus curiae on petition for rehearing to urge that the Court of Appeals for the Second Circuit overrule its earlier decision in the Rattner case. ${ }^{40}$ Thus the Commission, after further reflection and discussion with the members of the securities industry, either developed a less critical view towards the potential evils of the Blau decision, or the Commission decided that a flat prohibition on insider trading by broker-dealer firms, even with an ad hoc escape hatch, would not gain the necessary congressional support. Hence, rather than have the entire bill placed in jeopardy, ${ }^{41}$ the lesser and more moderate prophylaxis was chosen, namely, the general market-making exemption of section $16(\mathrm{~d})$.

The lengthy House hearings revealed that the Commission's distaste for its Special Study Group's enthusiastic suggestion of "re-

38 See Statement of the SEC, Hearings on S. 1642 Before a Subcomnittee of the Senate Committee on Banking and Currency, 88th Cong., 1st Sess. 401 (1963) [hereinafter cited as Senate Hearings].

39 See, e.g., the Commission's power to grant exemptions under $\$ 3$ of the Public Utility Holding Company Act of 1935, 49 Stat. 810, 15 U.S.C. \$79c (1958).

40 The Commission's petition was unfortunately denied. Blau v. Lehman, 286 F.2d 786 (2d Cir. 1960), rehearing denied per curiam, 286 F.2d 797 (2d Cir. 1961). See the dissenting opinion of Judge Clark for a strong statement of reasons why the Commission's petition should have been granted. Id. at 797-99. As his dissent points out, id. at 795-96, the Commission had previously indicated its doubt as to the wisdom of the Rattner decision in an amicus curiae brief which it had been permitted to file in that case.

41 See The Wall Street Journal, March 26, 1964, p. 2, col. 3. 
versing" Blau $v$. Lehman resulted at least partly from an equally enthusiastic reaction of appalled disbelief from the securities industry. As the Report itself indicated, if its suggestions were followed, a broker-dealer would be faced with the unappetizing alternative of either resigning from various boards or ceasing trading in the securities of the corporations involved, at least on a "short-swing" basis. Although, according to the Report, most partners when asked their choice between these two unpalatable alternatives indicated that they would rather resign than not trade, ${ }^{42}$ Blau $v$. Lehman was not likely to be reversed if it would result in such a lemming-like march away from the board rooms and back to the brokerage houses.

Those members of the House Subcommittee who opposed the section 16(d) exemption indicated, in their questioning of various witnesses, a suspicion that there was some form of dark alliance between the Commission and the securities industry, that the Commission had in effect capitulated to the industry's demands that the Special Study Group proposal be rejected. Consider the following colloquy between the Subcommittee Chairman, Representative Staggers, and Mr. Amyas Ames, President of the Investment Bankers Association of America:

Mr. STAGgers. . . . How did this section [Section $16(d)]$ happen to get into the bill which is before us?

Mr. Ames. It got into the bill because there was a surge of conviction on the part of the investment bankers across the country that it would be really wrong, just on a theory of distrust, to take the investment banking director off the board of a company or, conversely, to deprive that company of the right to have its stock sponsored by an investment banker. All across the country there are small companies that are being sponsored and nursed along and developed.

In the growth of the company, it is very important that more investors learn about the stock. It is important that that company's stock be sponsored. Once you start to put a curtain down around the company in the false idea that you are protecting somebody's morals, you will begin to hurt this operation. I think the logic was such that the bill was put into its present form.

Mr. StagGers. And I will ask you this again: In 1959, the recommendations as made by the Securities and Exchange Commission-and you say that was not your group, they 
are the arm of the Congress of the United States to regulate the securities and exchanges, and they are responsible to the Congress and not you and your group. But they are the ones who oversee.

I want to know if there is one recommendation made there that you then opposed that is contained in this bill which you know of.

MR. Ames. As far as the convictions of our group, we did go before the Securities and Exchange Commission and we did express our opinions very strongly on several points. Each of the points that we expressed a strong opinion upon some change was made. They did not accept our opinion all the way, but they did recognize the validity of our criticism and thoughts.

I think what you have before you is legislation where the best thinking of thoughtful men in industry, and the critical thinking of Government was modified or evolved or melded [sic] into a common piece of legislation.

Mr. Staggers. That is what I wanted to get at, that your Committee had great influence in the molding of this bill.

Mr. AmEs. I would not think great influence, sir, but I would think we did have influence, and I think it is very fine and as it should be that we were listened to. ${ }^{43}$

Near the conclusion of the hearings, another opponent of section 16(d), Representative Dingell, subjected Commission Chairman Cary to a rigorous cross-examination:

Mr. Dingelt. Mr. Cary, I noticed all through your statement . . you speak of section 16 of the act.

Mr. Cary. Yes, sir.

Mr. Dingell. Prescribing unfair use of insider information and also prescribing short-swing trading by insiders, $I$ assume that is a section which the Commission intends to continue supporting with enthusiasm. Am I correct?

Mr. Cary. Indeed it is.

Mr. Dingell. Mr. Cary, that is a very good point because that brings up something that has concerned me greatly with regard to the bill. That is simply this. I notice that the bill provides for a very serious weakening with regard to market makers in section 16 . Am I correct? 
Mr. CARY. I would say there is a definite provision making this inapplicable to market makers.

Mr. Dingell. Why should it not apply to a market maker then [?]

MR. Cary. We have had very substantial discussions with the industry on that.

Mr. Dingell. In other words, what you did was you held meetings with the industry and you simply agreed with the industry that you would afford industry exemption from the insider trading provisions of section (b) which we have already referred to as being particularly important and which are therefore embodied in the language of H.R. 6793. Am I correct?

MR. CARY. I think, in general, I agree with everything you said.

Mr. DingELL. In other words, you simply agreed with the industry that you would disregard the recommendations of the special study with regard to section $16(\mathrm{~b})$.

Mr. Cary. Let me say this in respect to market makers.

Mr. Dingell. In respect to market makers, the special study specifically deals with the problem of market makers and insider information, short-swing trading, does it not?

Mr. CARY. That is correct.

Mr. Dingell. And in effect you have completely disregarded the recommendations of the special study with regard to this particular point. Am I correct? the-

Mr. CARY. We pursued in general the theory that

Mr. Dingell. You are not answering my question.

MR. CARY. I will generally agree with you; yes, sir. I would like to make an explanatory statement at some point, but I agree with you. I think your criticism is perfectly appropriate, although I would have some explanation to give.

Mr. Dingell. As I have said before, Mr. Cary, I have a very high regard for you. I think you are a dedicated and a fine public servant, but on this particular matter [you] and I have some very substantial disagreement, because we spent over a million dollars of taxpayers' money to come up with a special study which I assume was carefully conducted by competent people, was it not? 
Mr. CARY. Yes, sir; which I am very proud of.

Mr. Dingell. You appointed them and you picked the most competent people you could lay your hands on, did you not?

Mr. Cary. Yes, sir.

Mr. Dingell. And one of their recommendations was directly in opposition to the provisions of subsection (b) .. . was it not?

Mr. Cary. Yes, sir; generally.

Mr. Dingell. And what happened was that you met with the industry and you decided, as you indicated in your response to Chairman Staggers of this subcommittee, that you would let them have a loophole more broad in the law than was already there.

Am I correct?

Mr. Cary. We gave, rather than the word "loophole," what I would regard as a limited exemption to market makers.

Mr. Dingell. So this is really the industry proposal that we have here. It is not the Commission proposal. It is not the proposal that was put forward by the special study. Would you agree with me on this last thought?

Mr. CARY. I would agree with you that the limited exemption is based on an industry committee recommendation; yes, sir. ${ }^{44}$

Even if the sentiment expressed by various members of the securities industry ${ }^{45}$ was a partial cause of the Commission's adoption of section $16(\mathrm{~d})$, there were other factors of substantial influence. For example, Commissioner Cary, in reply to Representative Harris' inquiry, indicated that the Commission preferred to concentrate on extension of section 16 to a larger number of companies and feared that controversy centering on section $16(d)$ might interfere with that goal. ${ }^{46}$

In summary it is possible to conclude that the prime motivating factors behind the Commission's choice of the section 16(d) general market-making exemption were: (1) its doubt that any other "solution" to the Blau problem would enlist legislative support in view of the prevailing attitude of the securities industry towards the Special

44 Id. at 1221-26.

45 These included the National Association of Securities Dealers, Inc. Id. at 614. $46 I d$. at 288 . 
Study Group proposal; (2) its fear that advocation of the legislative "reversal" of the Blau case would endanger the entire legislative program; and (3) its reluctance to "open up" the whole controversial status of section 16 itself by a prolonged debate on a subject about which the "industry feels very strongly." Thus it was content to receive half a loaf by sacrificing the possible advantages of the approach advocated by the Special Study Group.

In addition to political expediency, however, difficulties on the merits also plagued the Study Committee's proposal. The proponents of the bill argued essentially that the advantages of permitting small corporations to take advantage of the services of market-makers outweighed the possible dangers of abuse of the exemption and that the reporting requirement of section $16(\mathrm{a})$, applicable to market-makers as well as other insiders, gave the Commission ample supervisory and disciplinary powers over those who might utilize the exemption to take unfair advantage of the privileges it affords. ${ }^{47}$

Throughout the discussion on the floor of the House several assumptions were never adequately explored. The first is that the market-maker, in order properly to perform his function, must have access to "inside" information not available to the securities industry generally. Thus Representative Harris stated:

[The market-maker] in order to make the market for this company that is unable to get the capital must have information relative to the corporation's activities. Therefore, it is provided that he can be a part of that organization and sit in on the meetings of the members and therefore obtain this information in order that he can use this information to make a market for the securities they are not able to obtain otherwise. ${ }^{48}$

This is a curious statement. It does not make clear why certain information, allegedly available only by permitting the market-maker to be a director, is a prerequisite for his proper performance of his function. It certainly does not explain why the New York and American Stock Exchanges expressly prohibit specialists, whose function

47 See 110 CoNG. REc. 17330 (daily ed. Aug. 4, 1964) (remarks of Representative Glenn); 110 Cong. REc. 17598 (daily ed. Aug. 5, 1964) (remarks of Representative Keith) (implying that the reporting requirements will mean that the market-maker must "carry on his trading activity in a "fish bowl" "). If the Commission should find that "a broker-dealer uses inside information in this manner for his own gain, [it] has the power to put him completely out of business if it wishes to." Ibid. This statement was made in the context of a reference to a recent disciplinary proceeding which resulted in suspension of trading privileges, evidently Cady, Roberts \& Company. See Cady, Roberts \& Co., SEC Securities Exchange Act Release No. 6668 (Nov. 8, 1961), in 61-64 CCH FED. SEC. L. REP. $\mathbb{7} 76803$.

48110 Cong. REC. 17332 (daily ed. Aug. 4, 1964). 
it may be to make a market, ${ }^{49}$ from acting as directors of the concerns in whose stocks they specialize. ${ }^{50}$ Furthermore, there is a tacit assumption that the market-maker, once possessed of this "inside" information, will necessarily use it to direct his trading activities in the public interest. Thus information which would lead a prudent investor to sell would cause a market-maker to purchase, in order to maintain confidence in his corporation, and vice versa. Although this is supposedly the behavior pattern of the specialist on the stock exchange, who is prohibited from being a director and thus presumably does not have comparable access to inside information, ${ }^{51}$ one may well question whether the insider-market-maker, possessed of information of potentially critical relevance to the market price, is going to react as altruistically. In fact, since by hypothesis the information has not yet become available to the financial community generally, the market-maker is afforded an opportunity to utilize it to his own advantage and then subsequently to conceal his profit taking by purchases ostensibly to stabilize the falling market caused by public announcement of the adverse news. The market-makers "service" will be largely illusory if he has sold out a large position in a security and taken subsequently only a small one by way of purchase.

49 For the distinction between a specialist and a market-maker see the following colloquy between Senator Williams and Robert W. Haack, Member of the Board of Governors of the National Association of Securities Dealers:

Senator Williams. Does this [market-making] compare in any degree to the specialist who makes the market for a stock listed on one of the exchanges? Mr. HAACK. I would say there is a degree of similarity. One difference is that a specialist on the floor of an exchange sees almost all of the traffic in that particular security, whereas a marketmaker might be 1 of 10 or 15 or 20 people who would be acting as a principal, and he would not be exposed to all of the trading that takes place. But there is a comparability of function.

Senate Hearings 71. But see House Hearings 1227-28 (remarks of Chairman Cary): With regard to listed securities which are on exchanges, you are dealing with an auction market-primarily transactions between public buyers and sellers - in which the transactions, the purchase and sale transactions, are recorded. In the over-the-counter market you are primarily dealing only through marketmakers-who are willing to take positions and develop a market in a stock. Also many over-the-counter companies are new companies that need their underwriter both as a director and as a marketmaker. It is a different group. It is a different market.

Neither statement is entirely accurate. Although in many instances there may be a qualitative distinction between the type of trading which takes place over-the-counter and that which is carried on by means of the exchanges, where the market in a listed security is "thin" and the services of the specialist become more essential to maintaining liquidity, his function may approach that of a market-maker. Conversely, where trading over-the-counter in a particular security is frequent and there is little difficulty in matching buy and sell orders, the market-maker may behave much like a specialist.

50 See Special Study, pt. 3, at $44 \mathrm{n} .88$ indicating that the New York Stock Exchange's prohibition "extends not only to the specialist but also to the partners or stockholders of the firm to which he may belong, and any firm employee."

51 This behavior pattern may, in some instances, be more an ideal than a reality. See Special Strdy, pt. 2, at 96-121 (analyzing specialists' activities in a number of securities during the May 1962 market break). 
In this atmosphere, subject to obvious temptations, but free from many of the controls which govern the activities of specialists, only the most loyal and public spirited market-makers are likely to emerge Simon pure. True, section 16(a) may force them to carry on such activities in a "fish-bowl" environment, with potential drastic penalties for abuse of inside information to their own advantage. ${ }^{52}$ However, is the risk of such information being abused and the abuse being overlooked greater than the benefits which are supposed to accrue from its possession? The various exchanges apparently think so.

A further assumption remains to be explored. Throughout the House discussion the primary justification for the section 16(d) exemption was generally asserted to be the fledgling company:

When a small company is organized there is no market for its securities. The issues are not such that large underwritings can be effected. Consequently, someone, usually someone closely connected with the corporation, must take the chance of buying and selling the stock on his own account until a market can be established. ${ }^{53}$

Unquestionably, in the period following the initial public financing of a small concern, it is desirable that someone be available to make a market. As Representative Keith pointed out in the House debate, such market-making performs a dual function in providing a "central location to which orders flow" and also in adding marketability and liquidity to the securities, thereby increasing their value for lending purposes (e.g., margin) and otherwise. ${ }^{54}$ However, the Special Study Group arrived at a definite conclusion that "board representation is certainly not necessary to making a market." "55 In fact the Study Group felt that if the so-called "sponsors" or "market-makers," who are represented on the board of directors, were to withdraw from trading, the ensuing gap "would in most instances be filled by some other market maker" and thus in all likelihood the effect on the general market for the company's securities would be negligible. ${ }^{66}$ In fact most concerns if faced with the alternative of being represented on a board of directors or "making a market" would choose the

¿2 See note 47 supra (remarks of Representative Keith). But see text accompanying note 69 inffra.

53110 CoNG. REc. 17327 (daily ed. Aug. 4, 1964) (remarks of Representative Springer); accord, id. at 17330 (remarks of Representative Glenn).

54 Id. at 17599 (daily ed. Aug. 5, 1964).

55 Special Study pt. 3, at 49.

56 Id. at 51. For more precise definitions of "market-making" and "sponsorship," see $i d$. at $45 \mathrm{nn} .90$ \& 91 . 
latter. ${ }^{57}$ There is no indication that they would perform their functions as market-makers any less efficiently.

Furthermore, section 16(d) may serve to insulate supposed market-makers from liability long after the corporate gestation period has passed, since its scope is not limited to the small company toward which it was primarily directed. To be sure, the precise boundary of the rule is to be set by the Commission through exercise of the rulemaking powers expressly granted it in Section 16(d) to "define and prescribe terms and conditions with respect to ... transactions made in the ordinary course of business and incident to the establishment or maintenance of a primary or secondary market." Thus, presumably, if a corporation were to become large enough, or trading in its securities were to become so widespread as to eliminate the need for the services of a market-maker, the Commission might well declare it ineligible for the section 16(d) exemption. However, this appears to be a particularly difficult area in which to set boundaries or even guidelines. It will be interesting to see what success the Commission attains in doing so. ${ }^{58}$

On the assumption that such boundaries do exist, despite the difficulty in delineating them, there are still problems regarding the proper treatment under section 16 (b) of companies which do not qualify for the section 16 (d) exemption. Although Blau v. Lehman involved listed securities and not over-the-counter transactions, there seems to be no reason why it should not be applicable to the latter as well, to the extent that they fall within the amended section $16(\mathrm{~b})$ and yet fail to qualify for the section 16 (d) exemption. Also, since section $16(d)$ is, of course, expressly inapplicable to transactions on national securities exchanges, ${ }^{69}$ the Blau case remains in effect here

57 Id. at 48.

58 Until now the only indication of the Commission's position in this regard is the following:

As noted, the exemption is limited to transactions by dealers in securities for which they are making a market. Thus, at the time of the transaction, the dealer must have been indicating his willingness to other brokers and dealers to buy and sell such securities on a regular basis for his own account at realistic prices. A dealer, generally considered by other brokers or dealers having orders to buy or sell a security as the principal source or market for the execution of such orders, is regarded as making the primary or principal market. Secondary markets are made by dealers who trade in a security regularly, but on a more limited basis. A transaction by a dealer would not be exempt if incident to a market established or maintained by another dealer.

Senate Hearings 359 (Technical Statement of the SEC Relating to S. 1642). The Commission has indicated its intention to issue regulations under Section 16 (d) by "late 1964." House Hearings 221 (Technical Statement of the SEC on H.R. 6789, H.R. 6793, and S. 1642).

59 This was made clear in an amendment to the proposal by the Senate Banking and Currency Committee. See S. ReP. No. 379, 88th Cong., 1st Sess. 105 (1963). 
until overruled. Hence, deputization remains relevant in these two areas. It remains to be considered whether this test is realistic and fair and whether it achieves the statutory objectives.

\section{Deputization as a Test}

It will be recalled that the concept of deputization had its origin in the concurring opinion of Judge Learned Hand in Rattner $v$. Lehman Bros. ${ }^{60}$ This suggestion was the decisive factor in the Blau case, where the district court expressly found "no evidence that the firm of Lehman Brothers deputed [the individual insider defendant] . . . to represent its interest as a director on the Board of Tide Water; in fact, the interests of Lehman Brothers in Tide Water at the time Thomas was elected to be a director were minimal." 61 Whether the question of deputization is one of fact or of law is not crucial to this discussion except insofar as the finding of an absence of deputization was affirmed on appeal in the factual situation of the Blau decision. The salient facts are set forth in the district court opinion:

In 1954, at the age of 76 , defendant John Hertz, then a partner of Lehman Brothers, resigned his directorship of Tide Water. After resigning he spoke with Mr. Staples, President of Tide Water, and recommended defendant Thomas as a prospective director of Tide Water. Hertz then asked Thomas whether he would like to become a director of Tide Water and Thomas said that he would. $\mathrm{Mr}$. Thomas was then introduced to Mr. Staples at the home of John Schiff, a friend of $\mathrm{Mr}$. Thomas and a partner of Kuhn, Loeb \& Company. Staples and Thomas then met several times, culminating in Staples asking Thomas if he would like to be a director. The invitation to join the Tide Water Board was upon the initiative of Tide Water. Thomas accepted the directorship because of his interest in the oil business and because of the prestige factor in serving on the Board of a large corporation. ${ }^{62}$

It is possible to conclude from this vignette that deputization in the generally accepted sense of the term was present in Blau. Surely it is difficult to think that Thomas would have been fortunate enough to receive the bid to become a director of Tide Water if it had not been for the retirement of his partner, Hertz, as a director and the assistance

60193 F.2d 564, 567 (2d Cir. 1952).

61 Blau v. Lehman, 173 F. Supp. 590, 593 (S.D.N.Y. 1959), aff'd, 286 F.2d 786 (2d Cir. 1960), aff'd, 368 Uं.S. 403 (1962).

62173 F. Supp. at 592 . 
of the latter in calling Thomas to the attention of Staples. The courtship which followed seems but the pleasant social formality which confirmed Thomas as a member of the Tide Water establishment. Like many associations, business and otherwise, the initial stage of tentative approval is the critical one. The aftermath of meetings and dinner invitations is more ritual than part of the screening process.

In all probability, then, the resolution of the question of Thomas' deputization by Lehman Brothers to represent its interests depends on an examination of the status of his predecessor, Hertz, whose shoes he filled. Oddly enough, Hertz was the partner who had been a defendant in the Rattner case. Here, with respect to a different company, Consolidated Vultee Aircraft Corporation, the court found that Hertz had not been deputized by Lehman Brothers, or so we must assume from the implication of Judge Hand's dictum. But this conclusion had no probative weight with regard to Hertz's status several years later in a different corporation. The only permissible conclusion is that the partners of Lehman Brothers frequently sat as directors of corporations, a situation not at all unusual in the securities business. ${ }^{63}$ This fact of financial life does not answer the question whether particular partners have been deputized by their respective firms. If deputization was not shown in either the Blau or the Rattner cases, subsequent plaintiffs will have a heavy burden of proof to meet unless, by means of a presumption or otherwise, the shoe is to be placed on the other foot. Essentially it is this problem of proof which makes the deputization test unsatisfactory. Only the firm and its partners are in a position to ascertain the true relationship, and they are likely to maintain that the directorship of the insider had nothing to do with firm business but was a matter entirely personal to the individual.

Aside from problems of proof, it is difficult even to define "deputization." It is certainly unrealistic to make its presence dependent upon the intent with which the insider-partner was made a director initially, as if the firm were expected to instruct the partner, "Go and represent our interests on the Board." Although this may occur on occasion, the test of deputization, if it is to be at all adequate, must be broadened to raise the question whether the insider in subsequent years does in fact represent the interests of his firm, although initially he may not explicitly have been ordered or even

43 Lehman Brothers had partners on 100 boards of directors. 368 U.S. at 414 (Douglas, J., dissenting). See generally Comment, Securities Regulation: Irsider Status ir Legal Fiction and Financial Fact-A Proposed Revision to Section 16(b), 50 CALIF. L. REv. 500, 506-07 (1962). 
intended to do so. Did Thomas ever convey inside information to his partners? Did they act upon it? Here the opinion of the district court in Blau is remarkably reticent, stating only that the transactions which gave rise to the liability were carried out "without any advice or concurrence of Thomas, or without his knowledge until after the transactions had taken place," and that he had not been consulted by any of his partners with regard to Tide Water affairs "except to say to them that he believed it was a good company under good management." ${ }^{4}$ Judge Clark's dissent, however, suggests that Thomas' representation on the Tide Water board may have been, at least in part and perhaps quite substantially, a benefit to his firm. ${ }^{65}$

If the term "deputization" is broadly construed to include an insider's presence on a board of directors which is significantly beneficial to his firm, without raising the difficult causal question as to whether he thereby was a director because of the benefits which resulted, we are still left with problems of proof analogous to those dealt with above. ${ }^{66}$ How are we to show that the firm actually used inside information communicated by the insider-partner? Who is to recall precisely the small talk of the two-martini lunch of fellow partners or what action resulted therefrom? In fact the insider need not communicate at all with his firm since information released to a few close friends in the closely-knit financial community will likely come home to roost, whether the original publication be in a conversation on the morning train from Greenwich or at the nineteenth hole. This difficulty was of course uppermost in the minds of those

64173 F. Supp. at 592.

65 See 286 F.2d at 795 :

For in his deposition Thomas stated that he had suggested to his partners "from time to time that I thought Tide Water under the new management was an attractive investment" and again, "When the new management came in, my opinion was asked of what I thought of it, and after I watched them in, I expressed my opinion freely that I thought the management was firstrate, that the company would do well under that management." $\mathrm{He}$ also said that one of the partners with whom he discussed the Tide Water management after he became a director was Mr. Hammerslough, the trading partner who actually directed the firm's purchases of Tide Water stock; and Hammerslough himself testified on deposition that after Thomas became a director he "spoke very highly of the management and prospects of the Tide Water Oil Company. I believe he thought very highly of it." Unless judges are to be incredibly naive as to the facts of financial life, it is difficult to see what Thomas needed to say more to show that the lily was already gilded. The facts as to the proposed Tide Water exchange were published in the Wall Street Journal so that further details as to that would have been quite superfluous. In fact I regard all this discussion whether or not the firm "deputed" its members to sit on many corporate boards as naive. Obviously this was an arrangement of mutual benefit to both sides; what difference can it make in realities which extended the first invitation? And what further official "deputation" is needed more than the mere fact of this mutually beneficial management?

66 See p. 376 supra. 
who drafted section $16(\mathrm{~b})$. If the draftsmen found the problem of proof insuperable and thus adopted the "objective" standard, did Congress intend to subject section $16(\mathrm{~b})$ to similar problems when the firm's liability is involved? At the very least, a presumption of deputization should operate in the plaintiff's favor since only the defendant firm is in possession of the actual facts. ${ }^{67}$

To recapitulate: In order to establish section $16(\mathrm{~b})$ liability with regard to a broker-dealer in a Blau $v$. Lehman situation, a plaintiff must overcome at least two obstacles. Initially he.must show that the section 16(d) exemption does not apply. Then, once outside the scope of the exemption, he must establish that the defendant firm deputized the insider-partner to represent it on the corporation's board of directors. It has been suggested that the disadvantages inherent in the deputization test, and its possible conflict with the legislative intent of section $16(\mathrm{~b})$, would be lessened and the test itself rendered more palatable by shifting the burden of proof, or at least establishing a presumption in the plaintiff's favor, with regard to the issue of deputization. Similarly, the burden of proof with respect to the first obstacle, the applicability of the section 16(d) exemption, should be placed upon the defendant. This is especially true in view of the familiar principle of strict construction of exemptive clauses which requires the party seeking the exemption to establish that he falls within its terms. Both of these ameliorative measures could be effected without further amendment of the statute. Deputization is a judicial gloss on section 16(b), and its evidentiary burden can be distributed without an express overruling of either the Blan or Rattner cases.

If section 16(d) and the deputization test are interpreted as suggested above, the two, along with wise use by the Commission of the rule-making powers expressly delegated to it by section $16(\mathrm{~d})$, will probably be adequate to cope with the potential problems in this area, particularly when supplemented by the other investigative and disciplinary powers of the Commission exemplified in the Cady, Roberts case. ${ }^{68}$ Only one further problem remains.

\section{Disclosure}

A justification offered for section $16(d)$ is that abuse of the exemption will be prevented by the necessity that a market-maker

67 Compare the overall skepticism of Judge Clark's dissent in Blau v. Lehman, 286 F.2d 786, 793 (2d Cir. 1960), with the attitudes of various members of the securities industry elicited by the Special Study Group, Special Study, pt. 1, at 432-37.

68 Cady, Roberts \& Co., SEC Securities Exchange Act Release No. 6668 (Nov. 8, 1961), in 61-64 CCH FED. SEC. L. REP. \76803; see note 47 supra. 
conduct his activities in a "fish-bowl" atmosphere, due to the reporting requirements of section $16(\mathrm{a})$. Oddly enough, however, the latter does not by its terms require the market-maker to file reports. It requires reports to be filed by the beneficial owner of more than ten percent of any class of equity security, other than an exempted security, registered pursuant to section 12 of the act and by a director or officer of the issuer of any such security. Thus unless the market-maker is a beneficial owner of more than ten percent of the equity security, or is a director or officer of the issuer, technically it need not file reports. This is indeed odd, since it has apparently been assumed that all market-makers would be required to file under section $16(a) .^{69}$ As a practical matter if we view a market-maker as a broker-dealer who is either a director himself or has one of his partners on the board, the market-maker's transactions must be reported, but not necessarily by him. If he is himself a director, then he is expressly subject to the reporting requirement. If his partner is a director, then the partner must report and, in doing so, indicate the transactions of the firm of which he is a partner. This is required by the Commission's instructions to forms 3 and 4 under section 16(a). At the very least the Commission should promulgate this requirement as a rule rather than as an instruction to a reporting form. ${ }^{70}$ Indeed, for dual reasons it should go further and require that in all cases the firm, rather than merely the partner in some instances, report the transactions. First, there may be cases like the Blau situation where the transactions are effected without the knowledge of the insider-partner, who would then obviously be in a poor position to disclose what is unknown to him. His ignorance would be an easy method of insulating him from the reporting requirement. The second reason is that if the reporting duty were in all cases placed upon the firm, the likelihood of compliance would be increased since the responsibility would be pinpointed. Thus the firm would not be able to take advantage of its partner's inadvertent or intentional failure to comply, nor his lack of knowledge of the transactions in question. Similarly, if it were required to report in all cases, the question of the extent of its ownership would become immaterial.

\section{ConcLusion}

Although the Commission's initial reasons for proposing section $16(\mathrm{~d})$ are unconvincing, the exemption is in all probability the only

69 See, e.g., Senate Hearings 401 (Statement of the SEC); 110 CoNG. REC. 17598 (daily ed. Aug. 5, 1964) (remarks of Representative Keith).

70 For the history of the requirement see Painter, The Evolving Role of Section 16(b), 62 MICH. L. REv. 649, 662 n.44 (1964). 
type of legislation in this area which is feasible at this time. To supplement its deficiencies, the burden of proof should be placed upon the person claiming the exemption to show that he falls within its terms. Similarly, where the exemption does not apply, the burden of showing absence of deputization should be placed upon the defendant. Finally, the duty of reporting short-swing profits under section 16(a) should in all instances be placed upon the market-making firm rather than on the insider-partner. 